PART II

\title{
Remembrances of Former Students
}





\section{Remembrances of Former California College of Arts and Crafts Students}

Billy Al Bengston and Mel Strawn

\section{MEMORIES OF ARTIST BILLY AL BENGSTON}

Transcribed phone conversation, August 28, 2015; revised and approved by the artist.

Saburo taught painting at Arts and Crafts, but there was no painting in his class at all. I remember as a project he handed us four pieces of origami paper and said make a composition. Most people ripped these up and made tasteful compositions, but I crowded everything into one corner and he loved that.

His personality is what has always stuck with me. I have no idea what was on my mind at the time-but he came across loud and clear. By contrast, Diebenkorn-who was also my friend-seemed like a jerk, a conservative Army vet who was trying to make a living. But Saburo was majestic-he held a room-he was so fucking cool. Along with Pete Voulkos, he was the most authentic person I've ever met. He showed how a guy was supposed to act. When it rained, he walked into class in wooden geta. He wore his great-grandfather's robes. He was a living treasure of Japanese calligraphy. He didn't say much. I'd just listen to him breath.

Saburo had a show at the Oakland Museum and I was honored to assist him. He brought a roll of butcher paper, a bucket, a brush, a piece of string, and there must have been some ink. He measured the length of the wall with the string, and knotted it to show the length. He hadn't done any work in advance-but used knotted string to plan the scale of individual calligraphy works. He made all the work on butcher paper in two hours and hung it—and it was magnificent.

Saburo would come over to my place sometimes, and we'd all hang out. He smoked cigarettes and had a beer. He didn't eat much-although once he took us to a Chinese restaurant in Oakland, and when he walked in the staff snapped to attention. He had that kind of impact. He wasn't a big man-but he had a big impact. I can't imagine they make 'em like that any more. When I later saw Kurasawa's 
Yojimbo-I thought that Toshiro Mifune's character embodied what I saw in Saburo. I have since created works dedicated to both Hasegawa and Mifune.

\section{MEMORIES OF ARTIST MEL STRAWN}

From the website of Mel Strawn, who printed Hasegawa's lithograph Numbers One to Ten (https://beyond-calligraphy.com/2013/o2/21/saburo_hasegawa_asian_american_pioneer_of_abstract_calligraphy/).

When I went to his room to pick him up, Saburo asked me in and invited me to sit down. There was a paper screen opposite my place on the floor. A large, black-andwhite ink rubbing with the texture of wood grain was the image on the screen, the only art in sight. After looking for several minutes, I asked, "What is it?" Saburo said, "Nothing." Gradually I came to understand it to be $M u$, the Japanese (and Chinese) character that signifies "nothingness" or "emptiness."

I had promised to print a lithograph for Saburo and had told him- "Anytime, the stone is prepared." I had my own press and several lithographic stones on which the original image is drawn for later transfer to paper. On Monday night, after supper, Saburo appeared at our door and said he wanted to start the print. The stone was large and, like all lithographic stones, had a somewhat irregular edge. This is traditionally ignored, being marked off with a non-printing rectangular border inside the stone's edge. Saburo, however, started by placing a big sheet of paper over the stone and then rubbed around the edge with crayon, making the first mark that of the irregular edge itself. He then cut ten holes in the paper and taped it to the stone.

A necessary technical point: a lithographic image is made by drawing with a greasy crayon (or liquid) on virgin, grained limestone. The part touched by grease resists water. The untouched stone is physically and chemically treated with gum arabic, basically to resist oil and accept water on the open parts and to accept oilbased ink and reject water on the marked parts.

In the cut out spaces, Saburo wrote the numbers one to ten in Japanese characters, using a rectangular litho crayon instead of a brush. He then protected them (and some surrounding white space) with strips of cellophane tape. Some parts of the stone were still open-not covered by paper mask or tape. In these areas he stenciled greasy liquid tusche through our landlady's liberated lace curtain which he found in the basement where I kept my press. The "controlled accident" of this process left charred-looking blotches of textured black and white.

On the second day the paper mask came off and the stone's edge was already touched with grease, making the outline image of the stone itself susceptible to printer's ink. It would print, revealing the stone's natural and irregular shape. In the newly opened space between the cutout and numbers/shapes, Saburo gently drifted hard crayon across the finely ground, textured stone surface. 
The print which resulted, "Numbers One to Ten," is expressive of the wind, sand, charred wood Sunday picnic. Trees became the numerals-well, one can see it. The artist was Saburo Hasagawa (長谷川三郎), or Hasegawa Saburo in Japanese convention, possibly the first modern abstract artist in Japan. A world-traveled, world-class teacher, scholar, and artist, he lived, studied, worked, and taught in the United States and Europe as well as in Japan. He wanted to understand everything and to provoke consequences for the future art of both the East and West. It was 1955; he was my graduate teacher. In 1957 he died. He is still my teacher, although I am now considerably older than he was then.

A final note on the making of the print: after pulling the first proof the stone was closed. I opened it two days later, re-inked it, and pulled a second proof which had darkened, losing some of the silvery delicacy of the first proof which, of course, Saburo had seen. I took the new, darkened but richer version for him to see, full of foreboding that I had ruined it. He listened to my tale of woe about what had happened and then took a rather long time to study the new version. Finally he said, "It is better. Print the edition"-which I did. 